Proceedings

\title{
The Effect of Cooling Rate on Structure of Nitrided Layer Formed in Austenitic Stainless Steels
}

\section{オーステナイト系ステンレス鋼の窒化層組織に及ぼす冷却速度の影響}

\author{
Taka0 0htsuka**, Kuniyasu Gemma* and Mamoru Kawakami* \\ Department of Materials Science, Tokai University \\ 1117 K itakaname, Hiratsuka, Kanagawa, 259-12 Japan
}

( Accepted for publication 17 November 1994)

\section{1. 緒言}

T y p e 316 鋼の高温 $\left(800^{\circ} \mathrm{C}\right)$ 窒化層の棈造は冷却速 度により変化するとの報告がある。

本研究では、通常の窒化温度に拈けるオーステナイト系ステ ンレス鋼の空化層組織に及ほす冷却速度の影響を検討すること を目的とする。

\section{2. 実験方法}

供試材は溶体化処理したSUS 304 銚、S U S 316 鋼の 板材 (厚さ $2 \mathrm{~mm}$ ) を用い、これを $20 \mathrm{~mm} \times 30 \mathrm{~mm}$ に切出し、窒 化処理直前、アセトン中にて超音波洗浄を施したものを試験片 とした。

窒化処理は、竪型電気炉を用い、 $\mathrm{NH}_{\mathrm{a}}$ 雾囲気に保った石英 反応管内において $550^{\circ} \mathrm{C} 、 9$ 時間行った。 $\mathrm{NH}_{3}$ ガスの流晴

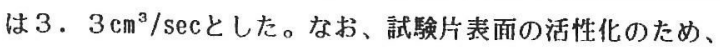
窒化直前、試験片を塭酸とエチルアルコール1 対 1 の湿合液に 浸し、表面のクロム酸化物保護皮膜を還元した。冷却は炉冷 ( $\mathrm{NH}_{3}$ 雾囲気中) 、空冷 ( $\mathrm{NH}_{3}$ 雾囲気中炉端冷却) 、水冷 （10\% N a OH水溶液中へ焼入れ）の3通りの方法で行った。 窒化処理後の試験片については、光学顕微鏡による断面組織 観察（腐食液はマーブル腐食液）、X線ディフラクトメーター によるX線回折を行った。X線回折は、試験片の表面及び表面

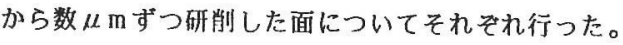

\section{3. 結果}

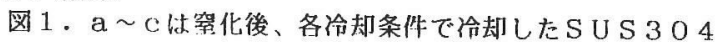
鋼の窒化層である。窒化層の厚さは、どれも約 $100 \mu \mathrm{m}$ であ り、組織についても特筆すべき違いはない。

図2.a〜cは同しくSUS 316 の窒化層である。これら の組織は冷却条作によって違いが顕著に現れ、かつ表面近くの 割れ、剥離がはなはだしい。これらのX R D パターンから同定 された相と表面からの深さの関係を表 1 に示した。水冷試料の み、表面近くに $\gamma 1 \mathrm{ike}$ 相が検出された。
表1.SU S 316 の表面からの深さと存在する相

\begin{tabular}{|c|c|c|c|c|c|c|c|c|c|}
\hline \multirow{2}{*}{ 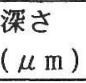 } & \multicolumn{3}{|c|}{ 炬泠 } & \multicolumn{3}{|c|}{ 空冷 } & \multicolumn{3}{|c|}{ 水冷 } \\
\hline & $\gamma$ & $\gamma^{\prime}$ & CrN & $\gamma$ & $\gamma^{\prime}$ & $\mathrm{CrN}$ & $\gamma$ & $\overline{\gamma^{\prime}}$ & $\mathrm{CrN}$ \\
\hline 0 & & (2) & (0) & & (a) & (0) & $\Delta$ & (2) & (a) \\
\hline 5 & & () & (9) & & (2) & (0) & $\triangle$ & (2) & (2) \\
\hline 10 & & (2) & (2) & $\triangle$ & (9) & 0 & $\Delta$ & (2) & (2) \\
\hline 15 & & (2) & (a) & $\triangle$ & (a) & 0 & $\Delta$ & 0 & 0 \\
\hline 20 & $\Delta$ & 0 & 0 & 0 & 0 & 0 & 0 & 0 & 0 \\
\hline 40 & 0 & 0 & $\mathrm{O}$ & 0 & 0 & $\mathrm{O}$ & 0 & $\mathrm{O}$ & 0 \\
\hline 60 & (2) & 0 & 0 & (2) & $\Delta$ & 0 & (2) & $\Delta$ & 0 \\
\hline 80 & (2) & $\triangle$ & 0 & (2) & $\triangle$ & $\Delta$ & (2) & & 0 \\
\hline
\end{tabular}

(○): 強い $\mathrm{O}$ : 普通 $\triangle$ : 弱い 無印: 存在せず

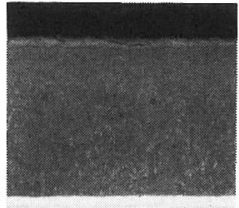

(a)

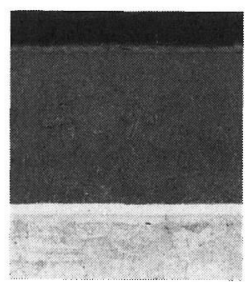

(b)

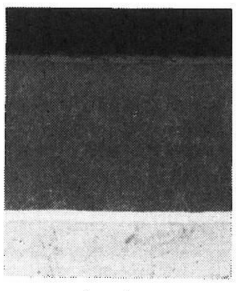

(c)
図1.SUS 304 の窒化層組織写真

(a) 炉冷 $(\mathrm{b})$ 空冷 $(\mathrm{c})$ 水冷

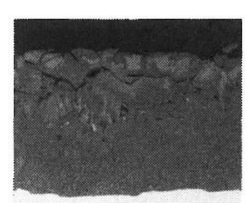

(a)

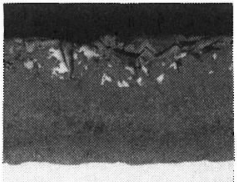

(b)
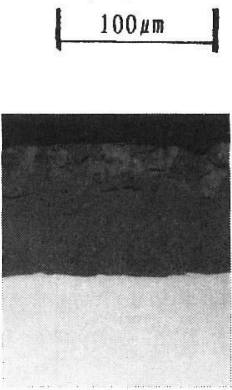

(c)

图2.SUS 316 の窥化層組織写真

(a) 炉冷 (b) 空冷 (c) 水冷

\section{参考文献}

${ }^{1}$ B.Billon and A.llendry : Surface Engineering 1 (1985) P. 114-130

'94 SAS Intelligent Symposium 